\title{
STRATEGI PENGEMBANGAN PERIKANAN TANGKAP TERPADU BERBASIS SUMBERDAYA UNGGULAN LOKAL: STUDI KASUS PERIKANAN CUMI DI KABUPATEN BANGKA SELATAN
}

\section{THE INTEGRATED DEVELOPMENT STRATEGIC OF CAPTURE FISHERIES WITH BASED ON LOCAL SUPERIOR RESOURCES: CASE STUDY OF SQUID FISHERIES IN SOUTH BANGKA REGENCY}

\author{
Mulyono S. Baskoro* dan Mustaruddin \\ Departemen Pemanfaatan Sumberdaya Perikanan, FPIK-IPB, Bogor, 16680, Indonesia \\ *E-mail: baskoro.mul@gmail.com
}

\begin{abstract}
Squid resources are the fisheries potention has important economic value in South Bangka Regency. Demand for this commodity in both fresh and processed forms is estimated to continue to increase in the future. This study aims to analyze the contribution of squid fisheries, analyze their development bases, and formulate development strategies in South Bangka Regency. This study used descriptive method, LQ analysis, and AHP method. During the period of 2009-2016, the production of squid fisheries in South Bangka Regency averaged 4187.87 tons with a contribution value of Rp87,736,058,000.00 annually. This squid production follows a polynomial pattern $y=-192.1 x 2+$ 1624. $x+1745\left(R^{2}=0.289\right)$. The base area for squid fisheries development uses: (1) liftnet is Tukak Sadai District, Lepar Pogok District, and Toboali District, (2) boat liftnet is Pongok Islands District, and (3) squid fishing is Simpang Rimba District, Batu Betumpang District, Toboali District, and Lepar Pongok District. While the priority development strategy is the coaching of human resources for squid fisheries (priority I) and improved management of the squid fisheries business (priority II) in each base area.
\end{abstract}

Keywords: base area, local superiority, priority strategy, squid fisheries

\begin{abstract}
ABSTRAK
Cumi merupakan potensi perikanan yang bernilai ekonomis penting di Kabupaten Bangka Selatan. Permintaan komoditas ini baik dalam bentuk segar maupun olahan diperkirakan terus mengalami peningkatan dimasa mendatang. Penelitian ini bertujuan untuk menganalisis kontribusi perikanan cumi, menganalisis basis pengembangannya, serta merumuskan strategi pengembangannya di Kabupaten Bangka Selatan. Penelitian ini menggunakan metode deskriptif, analisis LQ, dan metode AHP. Selama periode 2009-2016, produksi perikanan cumi di Kabupaten Bangka Selatan rata-rata 4187,87 ton dengan nilai kontribusi mencapai Rp87.736.058.000,00 setiap tahunnya. Wilayah basis pengembangan perikanan cumi menggunakan: (1) bagan tancap adalah Kecamatan Tukak Sadai, Kecamatan Lepar Pogok, dan Kecamatan Toboali, (2) bagan perahu adalah Kecamatan Kepulauan Pongok, dan (3) pancing cumi adalah Kecamatan Simpang Rimba, Kecamatan Batu Betumpang, Kecamatan Toboali, dan Kecamatan Lepar Pongok. Strategi prioritas pengembangan adalah pembinaan sumberdaya manusia perikanan cumi (prioritas I) dan perbaikan manajemen usaha perikanan cumi (prioritas II) di setiap wilayah basis pengembangan perikanan cumi.
\end{abstract}

Kata kunci: perikanan cumi, strategi prioritas, unggulan lokal, wilayah basis

\section{PENDAHULUAN}

Pemanfaatan potensi kelautan dan perikanan Indonesia belum dilakukan secara optimal. Salah satu penyebabnya adalah belum dilakukannya kegiatan pemanfaatan dengan basis pada sumberdaya unggulan lokal yang terdapat di setiap wilayah. Hal ini antara lain terlihat dari fluktuasinya hasil tangkapan nelayan meskipun sumberdaya 
ikan di perairan melimpah, penggunaan alat tangkap yang tidak sesuai dengan ikan target, pengembangan usaha pengolahan yang bahan bakunya tidak melimpah di lokasi, serta berhentinya aktivitas beberapa usaha pendukung akibat pasokan energi yang tidak memadai. Menurut Sumaila et al. (2016) dan PEMDA Kabupaten Bangka Selatan (2011), kondisi tersebut sering terjadi dalam kegiatan pemanfaatan potensi perikanan daerah dan dapat menjadi penghambat pengembangan terutama berkaitan dengan peluang investasi perikanan tangkap. Jika ke depan kegiatan pemanfaatan di sektor perikanan didasarkan pada potensi sumberdaya unggulan yang ada, maka beberapa produk perikanan lokal yang bernilai ekonomis tinggi, akan dapat memberikan kontribusi maksimal bagi peningkatan kesejahteraan rakyat.

Kabupaten Bangka Selatan merupakan salah wilayah yang mempunyai peluang besar untuk mengoptimalkan sumberdaya perikanan unggulan yang dimilikinya. Hal ini karena sebagian besar wilayah Kabupaten Bangka Selatan merupakan kepulauan dan dikelilingi oleh perairan laut. Jika dilihat berdasarkan pembagian Wilayah Pengelolaan Perikanan Republik Indonesia (WPP-RI), maka perairan Kabupaten Bangka Selatan berada di WPP-RI 711. WPP-RI 711 yang wilayahnya mencakup Selat Karimata dan Laut Natuna merupakan jalur migrasi utama berbagai jenis ikan dari laut China Selatan ke perairan Indonesia dan Samudera Hindia (jalur Selat Malaka), atau sebaliknya. Di samping itu, perairan Kabupaten Bangka Selatan juga berbatasan langsung dengan WPP-RI 712 (PEMDA Kabupaten Bangka Selatan, 2011), sehingga peluang pemanfaatan potensi kelautan dan perikanan dapat ditingkatkan lagi.

Salah satu potensi sumberdaya perikanan di perairan Kabupaten Bangka Selatan yang bernilai ekonomis penting dan banyak dikonsumsi adalah cumi (Uroteuthis chinensis). Permintaan komoditas ini baik dalam bentuk segar maupun olahan diperkirakan terus mengalami peningkatan dimasa mendatang. Indikator yang menunjukkan hal tersebut adalah semakin banyaknya diversifikasi produk olahan cumi seperti kerupuk, getas, kemplang, dan abon berbahan baku cumi (DKP Provinsi Kepulauan Bangka Belitung, 2017). Cumi mempunyai produksi yang menjanjikan di perairan Kabupaten Bangka Selatan. Hal ini dapat dilihat dari produksinya yang relatif tinggi setiap tahunnya, meskipun dengan pola fluktuatif (PEMDA Kabupaten Bangka Selatan, 2017). Pengelolaan yang baik terhadap sumberdaya cumi ini terutama pada wilayah-wilayah yang dianggap sebagai basis produksinya, akan menjamin keterpaduan aktivitas yang menjamin keberlanjutan pemanfaatan di masa datang. Konsep tersebut merupakan kunci kesuksesan pembangunan perikanan, yang diharapkan dapat memperbaiki kondisi sumberdaya dan kesejahteraan masyarakat perikanan itu sendiri (Fauzi dan Anna, 2002). Penelitian ini bertujuan untuk menganalisis kontribusi perikanan cumi terhadap pengembangan kegiatan perikanan tangkap, menganalisis basis pengembangan perikanan cumi di Bangka Selatan dan merumuskan strategi pengembangan perikanan cumi di wilayah basis terpilih.

\section{METODE PENELITIAN}

\subsection{Lokasi dan Waktu Kegiatan}

Penelitian ini dilaksanakan di Kabupaten Bangka Selatan. Sedangkan lokasi pengambilan data adalah wilayah kecamatan pesisir yang banyak akvitas perikanan cumi di Kabupaten Selatan. Waktu pelaksanaan penelitian Agustus September - November 2017.

\subsection{Jenis Data dan Metode Pengumpulan Data}

Data yang digunakan dalam penelitian ini terdiri dari data primer dan data sekunder. Data primer mencakup data hasil tangkapan cumi, alat tangkap, kondisi usaha 
perikanan cumi, serta pendapat stakeholders terhadap pengembangan perikanan cumi. Sedangkan data sekunder terdiri dari data time series produksi cumi, sebaran nelayan dan usaha penangkapan cumi per wilayah, dan serta peraturan dan kebijakan yang terkait dengan perikanan tangkap di Kabupaten Bangka Selatan.

Data hasil tangkapan, alat tangkap kondisi usaha, serta pendapat stakeholders terhadap pengembangan perikanan cumi dikumpulkan melalui penyebaran kuesioner, wawancara, dan pengamatan langsung. Responden data hasil tangkapan, alat tangkap cumi, dan kondisi usaha perikanan cumi adalah nelayan pemilik/nakhoda yang berjumlah 5-10 \% dari populasi nelayan cumi. Sedangkan responden terkait strategi pengembangan perikanan cumi berjumlah 25 orang, yang terdiri dari perwakilan nelayan pemilik 18 orang, masyarakat 5 orang, dan pegawai instansi perikanan 2 orang. Dari 18 orang perwakilan nelayan pemilik diambil dari bagan tancap, bagan perahu, pancing masing-masing 6 orang. Pemilihan semua responden dilakukan secara purposive sampling dengan maksud supaya data dapat diberikan oleh orang yang mengerti betul tentang kegiatan teknis perikanan cumi per wilayah, serta berbagai kebutuhan untuk pengembangannya ke depan di Kabupaten Bangka Selatan. Sedangkan responden instasi perikanan adalah kepala bidang perikanan dan kepala seksi penangkapan di dinas Pertanian, Peternakan, dan Kelautan Kabupaten Bangka Selatan.

Pengumpulan data sekunder dilakukan melalui studi literatur terhadap hasil studi dan laporan kegiatan perikanan yang tersedia di Badan Perencanaan, Penelitian, dan Pengembangan Kabupaten Bangka Selatan, instansi perikanan, dan perguruan tinggi. Data sekunder juga dapat berasal dari penelitian terdahulu terkait pengembangan perikanan cumi secara terpadu.

\subsection{Analisis Data}

Analisis data dalam penelitian ini menggunakan metode deskriptif, metode location quotient (LQ), dan metode analytical hirerachy process (AHP). Metode deskriptif digunakan untuk menganalisis kondisi dan kontribusi perikanan cumi terhadap subsektor perikanan tangkap di Kabupaten Bangka Selatan. Maina et al. (2016) menyatakan bahwa metode deskriptif dapat menggambarkan dengan jelas kondisi subjek atau objek penelitian berdasarkan fakta-fakta kini yang tampak atau apa adanya. Hasil analisisnya selanjutnya disajikan dalam bentuk tabel, grafik atau gambar yang relevan.

Analisis LQ digunakan untuk menentukan wilayah yang tepat sebagai basis pengembangan alat tangkap tertentu untuk menangkap cumi di Kabupaten Bangka Selatan. Wilayah basis tersebut dicirikan oleh intensitas output yang lebih tinggi dibandingkan intensitas output di semua wilayah/daerah penelitian. Sedangkan besaran output tersebut diwakili oleh intensitas kegiatan perikanan cumi menggunakan alat tangkap tertentu (diwakili oleh jumlah nelayannya) di setiap wilayah kecamatan. Analisis LQ dirumuskan dengan persamaan matematis (Baer and Brown, 2006):

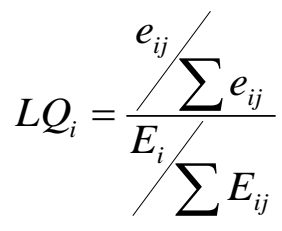

\section{Keterangan:}

$e_{i j}=$ Jumlah nelayan cumi dari alat tangkap ke-i di wilayah kecamatan ke-j, $\sum e_{i j}=$ Total jumlah nelayan cumi di wilayah kecamatan ke-j, $E_{i}=$ Jumlah nelayan cumi dari alat tangkap ke-i di seluruh wilayah kecamatan yang ada di Kabupaten Bangka Selatan, dan $\sum E_{i}=$ Total jumlah nelayan 
cumi di seluruh wilayah kecamatan yang ada di Kabupaten Bangka Selatan.

Untuk menginterpretasikan hasil analisis LQ, terdapat suatu kesepakatan sebagai berikut:

1. Jika nilai $L Q_{i}>1$, maka terjadi pemusatan intensitas pengembangan alat tangkap cumi ke-i di suatu wilayah kecamatan (wilayah basis).

2. Jika nilai $\mathrm{LQ}_{\mathrm{i}}=1$, maka intensitas pengembangan alat tangkap cumi ke-i di suatu wilayah kecamatan setara dengan kondisi umum pengembangan alat tangkap tersebut di Kabupaten Bangka Selatan (bukan wilayah basis).

3. Jika nilai $\mathrm{LQ}_{\mathrm{i}}<1$, maka intensitas pengembangan alat tangkap cumi ke-i di suatu wilayah kecamatan lebih rendah dari kondisi umum pengembangan alat tangkap tersebut di Kabupaten Bangka Selatan (bukan wilayah basis).

Metode AHP digunakan untuk menentukan strategi pengembangan perikanan cumi yang terpadu yang berbasis sumberdaya cumi. Pengembangan yang dimaksud adalah peningkatan jumlah (kuantitas) dan/atau efektifitas (kualitas) operasi alat tangkap tertentu untuk penangkapan cumi pada kecamatan yang menjadi wilayah basis berdasarkan hasil analisis sebelumnya. Strategi yang terpilih (prioritas) nantinya merupakan pertimbangan menyeluruh dari semua kriteria pengembangan, harapan dari stakeholders terkait, serta dan hal-hal menjadi pembatas dalam pengembangan perikanan tangkap yang berbasis sumberdaya cumi di Kabupaten Bangka Selatan.

Adapun tahapan analisis yang dilakukan adalah pendefinisian masalah /komponen dalam pengembangan perikanan tangkap berbasis sumberdaya cumi, penyusunan matriks hierarki dan pengumpulan data skala banding berpasangan, analisis banding berpasangan. Penetapan skala banding berpasangan mengacu kepada Saaty (1993), pengujian hasil analisis, mencakup pengujian rasio inconsistency (RI) dan sensitivity test. Hasil uji dinyatakan dapat diterima dan urutan prioritas strategi dapat dipercaya bila mempunyai nilai $\mathrm{RI}<0,1$ dan urutan prioritas terpilih tidak terlalu sensitif.

Supaya berhasil maksimal, maka strategi terpilih prioritas perlu didukung oleh prinsip pengelolaan perikanan tangkap yang baik dan bertanggung jawab. Penentuan prinsip pengelolaan tersebut selanjutnya dilakukan secara teorits dengan mempertimbangkan kebutuhan dari strategi terpilih.

\section{HASIL DAN PEMBAHASAN}

\subsection{Perkembangan Produksi Cumi}

Berdasarkan pola pendaratannya, produksi cumi di Kabupaten Bangka Selatan terbagi atas tiga, yaitu dari produksi cumi yang didaratkan di pangkalan pendaratan ikan (PPI) Sadai, produksi yang didaratkan di kecamatan kepulauan (Kec. Kepulauan Pongok dan Kec. Lepar Pongok), dan produksi yang didaratkan di lokasi pendaratan ikan yang tersebar di desa-desa nelayan di daratan Pulau Bangka. Produksi cumi yang didaratkan di PPI Sadai dan di kecamatan kepulauan terdata dengan lebih baik dibandingkan dengan di lokasi pendaratan ikan yang tersebar di desa-desa nelayan di daratan Pulau Bangka. Hal ini karena produksi cumi yang didaratkan di desa-desa nelayan tersebut relatif banyak dan tersebar, sehingga kurang terdeteksi. Gambar 1 menyajikan data perkembangan produksi cumi dalam tujuh tahun terakhir.

Berdasarkan Gambar 1, produksi cumi di Kabupaten Bangka Selatan selama tahun terakhir (periode 2009-2016) berfluktuatif, dengan jumlah rata-rata mencapai 4187,87 ton setiap tahunnya. Dari jumlah tersebut, sekitar 63,50 \% merupakan kontribusi bagan perahu, sedangkan sisanya berasal dari bagan tancap dan pancing, masing-masing hanya sekitar $25,15 \%$ dan $11,35 \%$. Namun demikian, trend produksi produksi tersebut cenderung menurun setelah mencapai kondisi produksi optimal. Trend produksi tersebut digambarkan dengan persamaan polynomial $y=-192.1 x^{2}+1624 . x$ 
$+1745\left(R^{2}=0,289\right)$. Pada persamaan tersebut, $\mathrm{y}$ adalah produksi dan $\mathrm{x}$ adalah tahun. Hal ini dapat terjadi karena kegiatan penangkapan yang berlebihan yang tidak sesuai dengan daya dukung potensi sumberdaya untuk pulih atau adanya intervensi kegiatan lain pada waktu-waktu tertentu yang merusak habitat cumi (Oktariza et al., 2016 dan Rosalina et al., 2011).

Nilai produksi cumi di Kabupaten Bangka Selatan mempunyai pola yang sama dengan jumlah produksinya (Gambar 2). Namun dengan trend peningkatan yang lebih baik, karena harga jual cumi yang cenderung meningkat setiap tahunnya. Pada tahun 2009, harga cumi hasil tangkapan nelayan di Kabupaten Bangka Selatan rata-rata $\mathrm{Rp}$ 17.500/kg, sedangkan pada tahun 2013 dan tahun 2016 masing-masing mencapai ratarata $\mathrm{Rp} 21.500 / \mathrm{kg}$ dan $\mathrm{Rp} 25.000 / \mathrm{kg}$. Nilai produksi cumi di Kabupaten Bangka Selatan rata-rata $\mathrm{Rp} 87.736 .058$ setiap tahunnya. Nilai produksi tertinggi terjadi pada tahun 2013, yaitu mencapai Rp 139.904.800.000 dan terendah terjadi pada tahun 2014 mencapai Rp 37.018.326.250.

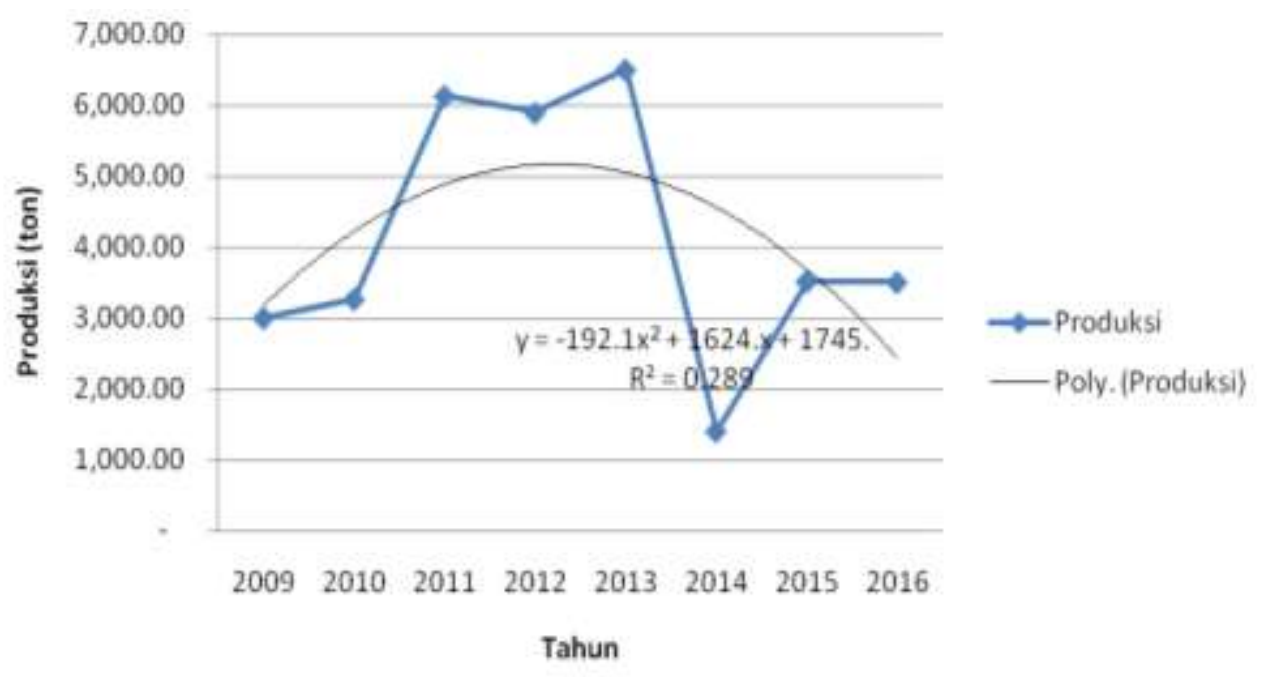

Gambar 1. Perkembangan produksi cumi di Kabupaten Bangka Selatan periode 2009 - 2016.

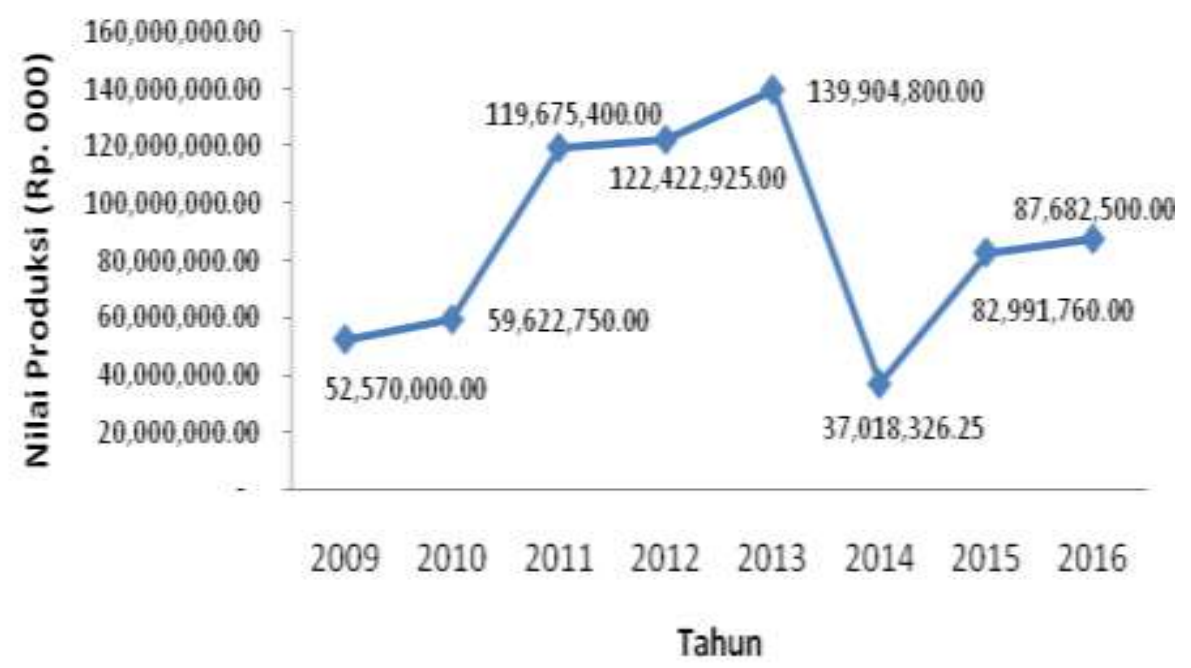

Gambar 2. Perkembangan nilai produksi cumi di Kabupaten Bangka Selatan periode 2009 2016. 


\subsection{Wilayah Basis Pengembangan Perikanan Cumi}

\subsubsection{Location Quotients (LQ) bagi Alat Tangkap Cumi}

Secara umum, Kabupaten Bangka Selatan terbagi atas delapan wilayah kecamatan, yaitu Kecamatan Toboali, Kecamatan Tukak Sadai, Kecamatan Batu Betumpang, Kecamatan Payung, Kecamatan Lempar Pongok, Kecamatan Simpang Rimba, Kecamatan Air Gegas, dan Kecamatan Kepulauan Pongok. Selama ini, kecamatan tersebut mempunyai intensitas usaha perikanan yang berbeda satu sama lain, dimana setiap kecamatan berkembang usaha perikanan berdasarkan jenis alat tangkap yang digunakan nelayan secara turun temurun. Beberapa ada yang mendapat introduksi teknologi dari luar/pendatang, tetapi hanya dalam desain bagian tertentu dari alat tangkap tersebut. Namun ada juga, wilayah kecamatan yang kegiatan perikanan sangat minim, yaitu Kecamatan Payung.

Analisis Location Quotients (LQ) yang dilakukan akan menentukan apakah wilayah kecamatan yang ada dapat menjadi sektor basis bagi pengembangan salah satu atau beberapa alat tangkap cumi di Kabupaten Bangka Selatan. Hasil analisis LQ tersebut dilakukan dengan pertimbangan bahwa nelayan merupakan tenaga kerja perikanan dan menjadi pelaku langsung untuk tumbuh dan berkembangnya alat tangkap cumi di Kabupaten Bangka Selatan. Tabel 1 menyajikan hasil analisis Location Quotients (LQ) bagi pengembangan tiga alat tangkap utama untuk cumi, yaitu bagan tancap, bagan perahu, dan pancing cumi.

Berdasarkan Tabel 1, bagan tancap mempunyai nilai LQ > 1, di Kecamatan Tukak Sadai, Kecamatan Lepar Pogok, dan Kecamatan Toboali yaitu masing-masing 7,96, 3,55, dan 2,33. Dengan demikian, Kecamatan Tukak Sadai, Kecamatan Lepar Pogok, dan Kecamatan Toboali dapat menjadi wilayah basis bagi pengembangan alat tangkap bagan tancap di Kabupaten Bangka Selatan. Untuk mendukung hal ini, maka nelayan yang mengembangkan alat tangkap tersebut dan pihak-pihak lain yang terlihat dalam pemasaran cumi hasil tangkapannya perlu diberikan pembinaan sehingga bagan tancap dapat berkembang lebih baik di kalangan nelayan dan menjadi andalan dalam produksi cumi di Kecamatan Tukak Sadai, Kecamatan Lepar Pogok, dan Kecamatan Toboali. Untuk mendukung hal ini, maka beberapa fasilitas terkait, seperti fasilitas TPI, usaha penyediaan bahan perbekalan maupun fasilitas jalan perlu dioptimalkan fungsinya. Saran dan prasarana pendukung yang memadai, tentu akan memudahkan pengembangan dan perbaikan alat tangkap, serta mempermudah akses penjualan cumi hasil tangkapan (Mustaruddin et al., 2015).

Tabel 1. Hasil analisis LQ alat tangkap cumi.

\begin{tabular}{lccc}
\hline & \multicolumn{3}{c}{ Nilai LQ } \\
\cline { 2 - 4 } Produksi Cumi & $\begin{array}{c}\text { Bagan } \\
\text { Tancap }\end{array}$ & $\begin{array}{c}\text { Bagan } \\
\text { Perahu }\end{array}$ & Pancing \\
\hline Kec. Toboali & 2,33 & 0,00 & 1,65 \\
Kec. Tukak & 7,96 & 0,00 & 0,99 \\
$\begin{array}{l}\text { Sadai } \\
\text { Kec. Batu }\end{array}$ & 0,00 & 0,00 & 1,93 \\
$\begin{array}{l}\text { Betumpang } \\
\text { Kec. Payung }\end{array}$ & 0,00 & 0,00 & 0,00 \\
$\begin{array}{l}\text { Kec. Lepar } \\
\text { Pongok }\end{array}$ & 3,55 & 0,00 & 1,51 \\
$\begin{array}{l}\text { Kec. Simpang } \\
\text { Rimba }\end{array}$ & 0,00 & 0,00 & 1,93 \\
$\begin{array}{l}\text { Kec. Air } \\
\text { Gegas }\end{array}$ & 0,00 & 0,00 & 0,00 \\
$\begin{array}{l}\text { Kec. } \\
\text { Kepulauan } \\
\text { Pongok }\end{array}$ & 0,00 & 1,46 & 0,75 \\
\hline
\end{tabular}

Bagan perahu mempunyai nilai LQ > 1 di Kecamatan Kepulauan Pongok, yaitu 1,46. Terkait dengan ini, maka Kecamatan Kepulauan Pongok dapat menjadi wilayah basis bagi pengembangan bagan perahu di Kabupaten Bangka Selatan. Populasi bagan perahu di Kecamatan Kepulauan Pongok relatif yaitu sekitar 145 unit dan menjadi menjadi satu-satu kecamatan di Kabupaten 
Bangka Selatan yang banyak mengembangkan bagan perahu untuk menangkap cumi. Wilayah perairan yang tenang dan relatif luas yang mengelilingi pulau memberi peluang besar bagi pengambangan alat tangkap yang dioperasikan secara aktif (Nurdin and Grydehoj, 2014; Mustaruddin et $a l ., 2014)$. Penggunaan bagan perahu ini juga membantu nelayan dalam distribusi hasil tangkapan cumi, mengingat wilayah kecamatan ini merupakan yang paling jauh dan terpisah dari kecamatan-kecamatan lainnya.

Wilayah untuk pengembangan pancing cumi di Kabupaten Bangka Selatan adalah Kecamatan Simpang Rimba (LQ = 1,93), Kecamatan Batu Betumpang (LQ = 1,93), Kecamatan Toboali ( $\mathrm{LQ}=1,65)$, dan Kecamatan Lepar Pongok (LQ = 1,51). Terpilihnya Kecamatan Simpang Rimba dan Kecamatan Batu Betumpang menjadi wilayah basis bagi pengembangan alat tangkap pancing. Berdasarkan data statistik, nelayan cumi di Kecamatan Simpang Rimba berjumlah 65 orang, dan semuanya menggunakan pancing untuk menangkap cumi. Sedangkan di Kecamatan Batu Betumpang ada 13 orang, juga semuanya menangkap cumi di pancing. Kecamatan Toboali dan Kecamatan Lepar Pongok juga menjadi wilayah basis bagi pengembangan alat tangkap pancing untuk cumi, meskipun alat tangkap lain untuk cumi juga berkembang. Hal ini karena populasi alat tangkap pancing relatif tinggi di Kecamatan Lepar Pongok ini, yaitu 120 unit. Sedangkan di Kecamatan Toboali, pancing menjadi alat tangjap paling dominan.

Menurut Sumaila et al. (2016) dan Su et al. (2016), untuk mendukung pengembangan alat tangkap, maka nelayan yang terlibat maupun namun tertarik bekerja pada usaha perikanan dimaksud perlu dibina dengan baik terutama dengan teknik penangkapan efektif, penanganan hasil, dan perawatan alat tangkap, sehinga usaha mereka dapat berkembang lebih baik. Bila hal ini berlanjut, maka produktivitas alat tangkap pancing di Kecamatan Simpang Rimba, Kecamatan Batu Betumpang, Kecamatan Toboali, dan Kecamatan Lepar Pongok, sehingga dapat diandalkan dalam memenuhi permintaan pasar cumi-cumi dari Kabupaten Bangka Selatan.

\subsubsection{Pertumbuhan Tenaga Kerja di Wilayah Basis}

Analisis pertumbuhan tenaga dimaksudkan untuk mengetahui tingkat pertumbahan ekonomi di wilayah basis bila alat tangkap cumi dikembangkan. Pertumbahan tenaga kerja ini merupakan cerminan dari pertumbuhan usaha perikanan cumi bila kegiatan pengembangan alat tangkap dilakukan terus di wilayah/ kecamatan yang menjadi basis pengembangannya. Nilai pengganda basis pada analisis sebelumnya akan menjadi peubah dalam penilaian pertumbuhan tenaga untuk setiap alat tangkap cumi di wilayah basis.

Dalam arti lebih luas, pertumbuhan tenaga kerja merupakan cerminan dari kontribusi sektor perikanan cumi dalam memacu pertumbuhan ekonomi masyarakat di Kabupaten Bangka Selatan. Hasil analisis pertumbuhan tenaga kerja di wilayah basis disajikan pada Tabel 2.

Berdasarkan Tabel 3.2, Kecamatan Kepulauan Pongok mempunyai pertumbuhan tenaga kerja paling baik dibandingkan kecamatan lainnya yang menjadi wilayah basis pengembangan alat tangkap cumi. Pertumbuhan tenaga kerja tersebut terjadi pada alat tangkap bagan perahu (191 orang/tahun). Pertumbuhan tenaga kerja bagan perahu paling tinggi di Kecamatan Kepulauan Pongok memberi indikasi bahwa alat tangkap tersebut telah berkembang dengan baik di Kecamatan Kepulauan Pongok, melebihi perkembangan yang terjadi di kecamatan lainnya. Kondisi ini bisa jadi karena intensitas penggunaan kedua alat tangkap yang tinggi di kecamatan tersebut dan hasil tangkapan yang didapat juga banyak. Sedangkan menurut De Freitas and Tagliani (2009), hasil tangkapan yang baik 
lebih mudah mendorong nelayan kecil/tradisional untuk mengembangkan alat tangkap secara luas.

Tabel 2. Pertumbuhan tenaga kerja (Delta N) di wilayah basis.

\begin{tabular}{lccc}
\hline \multirow{2}{*}{ Produksi TTC } & \multicolumn{3}{c}{ Delta N } \\
\cline { 2 - 4 } & $\begin{array}{c}\text { Bagan } \\
\text { Tancap }\end{array}$ & $\begin{array}{c}\text { Bagan } \\
\text { Perahu }\end{array}$ & Pancing \\
\hline Kec. Toboali & 1 & - & 4 \\
Kec. Tukak & 1 & - & - \\
Sadai & & & \\
Kec. Batu & - & - & 1 \\
Betumpang & & & \\
Kec. Payung & - & - & - \\
Kec. Lepar & 5 & - & 14 \\
$\begin{array}{l}\text { Pongok } \\
\text { Kec. Simpang }\end{array}$ & - & - & 6 \\
$\begin{array}{l}\text { Rimba } \\
\text { Kec. Air Gegas }\end{array}$ & - & - & - \\
Kec. Kepulauan & - & 191 & - \\
Pongok & & & \\
\hline
\end{tabular}

Pertumbuhan tenaga kerja di wilayah Kecamatan Lepar Pongok juga termasuk baik, dominan karena kontribusi alat tangkap pancing (14 orang/tahun). Bila ditunjau dari hasil produksi cuminya, Kecamatan Lepar Pongok memberi kontribusi produksi cumi terbesar kedua di Kabupaten bangka Selatan setelah kecamatan Kepuluan Pongok, yang mencapai 114,36 ton pada tahun 2013 dan 81,95 ton pada tahun 2014. Produksi cumi yang lumayan tinggi mendorong pengembangan alat tangkap dan tenaga kerja yang akan mengoperasikannya. Pertumbuhan tenaga kerja untuk bangan tancap di Kecamatan Lepar Pongok merupakan yang paling tinggi dibandingkan dua kecamatan lainnya (Kecamatan Tukat Sadai dan Kecamatan Toboali) yang menjadi wilayah basis pengembangan bagan tancap. Pertumbuhan tenaga kerja pada bagan tancap Kecamatan Lepar Pongok mencapai 5 orang/tahun, sedangkan di Kecamatan Tukat Sadai dan Kecamatan Toboali masingmasing 1 orang/tahun. Hal ini menunjukkan bahwa dukungan nelayan terhadap pengembangan perikanan cumi sangat tinggi di Kecamatan Lepar Pongok. Kondisi ini juga didukung oleh terbatas alternatif mata pencaharian di wilayah pulau dibandingkan dengan di daratan pulau, sehingga nelayan benar-benar fokus dalam pengembangan alat tangkap dari komoditas yang menjadi unggulan (Pascoe et al., 2014 dan Oktariza et al., 2016).

Bila diperbandingkan untuk semua wilayah basis dan semua alata tangkap cumi, maka pertumbuahan tenaga kerja yang rendah terjadi pada bagan tancap di Kecamatan Batu Betumpang, serta bagan tancap di Kecamatan Tukat Sadai dan Kecamatan Toboali, yaitu masing-masing hanya 1 orang/tahun. Kondisi ini cukup wajar karena jumlah tenaga kerja/nelayan dari alat tangkap terkait di ketiga kecamatan pada awalnya sudah rendah dan juga operasi penangkapan cumi biasa-biasa saja (tidak sangat aktif). Namun demikian, pertumbuhan tenaga kerja pancing di Kecamatan Tukat Sadai dan Kecamatan Toboali relatif bagus (masing-masing 4 orang/tahun), meskipun masih jauh dibandingkan dengan di Kecamatan Kepulauan Pongok. Terlepas dari dinamika pertumbuhan ternaga kerja yang terjadi di setiap kecamatan yang menjadi wilayah basis, pengembangan alat tangkap cumi tetap dapat dilakukan karena penggunaan alat tangkap tersebut relatif dominan dan mengakar di masyarakat (LQ > 1), untuk mendukung, maka jaringan pasar, sarana dan prasarana perikanan, serta kegiatan jasa pendukung harus diperhatikan, sehingga terjadi keterpaduan dan kontinyuitas kontribusi perikanan cumi terjadi dengan baik di Kabupaten Bangka Selatan. Program-program pemberdayaan dan pendampingan yang positif kepada nelayan harus terus dilakukan sehingga pengembangan perikanan cumi dapat memberikan manfaat yang lebih besar bagi kesejahteraan masyarakat nelayan dan perekonomian daerah. 


\subsection{Strategi Pengembangan Perikanan Cumi Sebagai Komoditas Unggulan Lokal}

\subsubsection{Pengembangan Strategi Prioritas}

Pengembangan strategi prioritas merupakan tujuan akhir dari penelitian pengembangan perikanan cumi ini. Strategi prirotas perlu ditentukan supaya pengembangan perikanan cumi dengan menggunakan alat tangkap tertentu dapat lebih terarah dan terpadu di beberapa kecamatan yang terpilih menjadi wilayah basis. Hal ini penting supaya tenaga dan sumberdaya dapat digunakan secara efektif dan efisien pada hal-hal yang dibutuhkan bagi pengembangan perikanan cumi di Kabupaten Bangka Selatan. Pengembangan yang dimaksud adalah peningkatan jumlah (kuantitas) dan/atau efektifitas (kualitas) operasi alat tangkap tertentu untuk penangkapan cumi pada wilayah kecamatan tertentu (wilayah basis) yang disarankan untuk dikembangkan. Strategi yang dikembangkan nantinya harus mampu mengakomodir maksud tersebut. Hasil survai lapang dan diskusi pakar berhasil mengidentifikasi enam opsi strategi yang bisa dikembangkan diajikan pada Tabel 3.

Menggunakan sofware aplikasi AHP (software TeamEC), didapat hasil analisis strategi prioritas seperti pada Gambar 3. Hal ini cukup wajar mengingat sumberdaya manusia, yang dalam hal ini nelayan cumi, kemudian pengolah dan pedagang cumi, merupakan pelaku langsung kegiatan perikanan cumi. Baik buruknya kinerja mereka akan menentukan ke-berhasilan kegiatan perikanan cumi di setiap wilayah yang menjadi basis pengembangan cumi di Kabupaten Bangka Selatan.
Tabel 3. Opsi strategi pengembangan perikanan cumi.

\begin{tabular}{|c|c|c|c|}
\hline \multirow[t]{2}{*}{ No. } & \multirow[t]{2}{*}{ Opsi Strategi } & \multicolumn{2}{|c|}{$\begin{array}{c}\text { Dukungan } \\
\text { Pengembangan }\end{array}$} \\
\hline & & Quant & Qual \\
\hline 1 & $\begin{array}{l}\text { Pengembangan } \\
\text { teknologi tepat guna } \\
\text { dalam operasi } \\
\text { penangkapan cumi } \\
\text { (TEKN-TG) }\end{array}$ & $\sqrt{ }$ & $\sqrt{1}$ \\
\hline 2 & $\begin{array}{l}\text { Pembinaan } \\
\text { sumberdaya manusia } \\
\text { perikanan cumi } \\
\text { (BINA-SDM) }\end{array}$ & $\sqrt{ }$ & $\sqrt{ }$ \\
\hline 3 & $\begin{array}{l}\text { Pengembangan } \\
\text { kredit usaha } \\
\text { pembiayaan } \\
\text { perikanan (KU- } \\
\text { BIAYA) }\end{array}$ & $\sqrt{ }$ & - \\
\hline 4 & $\begin{array}{l}\text { Perbaikan } \\
\text { manajemen usaha } \\
\text { perikanan cumi (MJ- } \\
\text { USAHA) }\end{array}$ & - & $\sqrt{ }$ \\
\hline 5 & $\begin{array}{l}\text { Perbaikan sistem } \\
\text { pengelolaan sarana } \\
\text { dan prasarana } \\
\text { perikanan (SAR- } \\
\text { PRAS) }\end{array}$ & $\sqrt{ }$ & - \\
\hline 6 & $\begin{array}{l}\text { Pengembangan zona } \\
\text { pemanfaatan dan } \\
\text { restocking (ZONA- } \\
\text { PR) }\end{array}$ & - & $\sqrt{ }$ \\
\hline
\end{tabular}

Menurut Baskoro (2016) dan Mustaruddin et al. (2015), faktor manusia merupakan penentu utama usaha ekonomi, dengan tingkat pengaruh mencapai 45-52\%. Sedangkan menurut Nurdin and Grydehoj (2014), pengembangan sumberdaya manusia menjadi prioritas dari banyak program Pemerintah di bidang usaha kecil dan menengah. 
Synthesis of Leaf Nodes with respect to GOAL

Distribute Mode

Overall Inconsistency Inde $x=0.005$

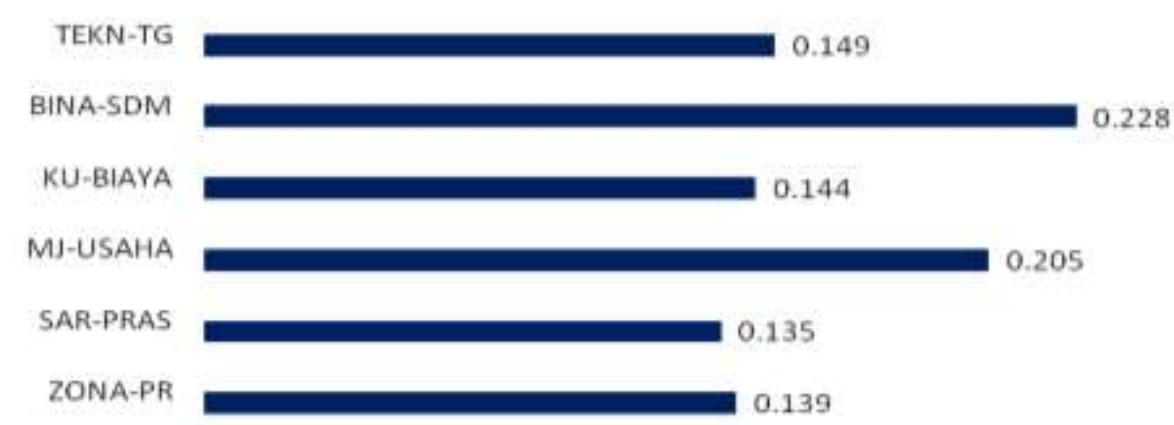

Gambar 3. Hasil analisis prioritas strategi pengembangan perikanan cumi sebagai komoditas unggulan lokal di Kabupaten Bangka Selatan.

Opsi strategi perbaikan manajemen usaha perikanan cumi (MJ-USAHA) menjadi prioritas kedua dalam mendukung pengembangan perikanan cumi sebagai komoditas unggulan lokal. Strategi MJ-USAHA ini dapat membantu nelayan, pengolah, dan pedagang cumi dalam menanaj keuangan dan kegiatan operasi perikanan yang dilakukannya sehingga lebih efisien dan kompetitif dalam menghasilkan produk cumi yang dibutuhkan pasar. Fitriyashari et al. (2014) menyatakan bahwa manajemen usaha yang buruk merupakan penyebab utama usaha perikanan sulit berkembang apalagi untuk memanfaatkan peluang pasar yang potensial. Sedangkan menurut Mustaruddin et al. (2015), manajemen usaha yang baik penting untuk meningkatkan kepercayaan konsumen terhadap kegiatan perikanan tangkap. Pengembangan teknologi tepat guna dalam operasi penangkapan cumi menjadi strategi prioritas ketiganya. Ketiga strategi prioritas tersebut perlu dilakukan dilakukan secara optimal oleh pihak-pihak terkait di daerah (Kabupaten Bangka Selatan) dan pusat, sehingga kontribusi perikanan cumi sebagai komoitas unggulan lokal terus meningkat. Nelayan, pengolah, dan pedagang cumi yang ada di wilayah basis pengembangan cumi, dapat menjadi dapat menjadi sasaran utama dari program-program implementasi dari ketiga strategi prioritas.

\subsection{Prinsip Pengelolaan yang} Mendukung Implementasi Strategi Prioritas

Supaya berhasil maksimal, maka implementasi strategi prioritas perlu didukung oleh prinsip pengelolaan perikanan tangkap yang baik dan bertanggung jawab. Hasil analisis menunjukkan bahwa paling tidak ada lima prinsip pengelolaan yang perlu diperhatikan dalam implementasi strategi pengembangan perikanan cumi di Kabupaten Bangka Selatan, yaitu: kelestarian sumberdaya, kelestarian budaya, akses ekonomi, partisipatif, serta akuntabilitas dan transparansi.

Prinsip kelestarian sumberdaya, perlu dikedepankan dalam implementasi strategi prioritas pengembangan perikanan cumi, karena pada dasarnya setiap kegiatan pengelolaan memiliki tujuan untuk meningkatkan kesejahteraan masyarakat. Oleh karena itu, kelestarian sumberdaya harus dipertahankan sebagai landasan utama untuk mencapai tujuan tersebut dan menjadi roh implementasi strategi prioritas. Pengembangan perikanan cumi di Kabupaten Bangka Selatan diharapkan tidak menyebabkan rusaknya fishing ground, spawning ground dan nursery ground ikan. Selain itu, tidak pula merusak hutan mangrove, terumbu karang, dan padang lamun yang memiliki keterkaitan ekologis dengan ikan. Kedua, 
kelestarian budaya. Strategi pengembangan perikanan cumi perlu dilaksanakan dengan memperhatikan kearifan/pengetahuan lokal, hukum adat dan aspek kelembagaan lainnya berkaitan dengan kegiatan tersebut yan ada di Kabupaten Bangka Selatan. Hal ini harus menjadi perhatian penting instansi terkait sehingga program yang digagasnya bersesuaian dengan tata nilai lokal dan hukum adat yang berlaku di kalangan masyarakat pesisir Bangka Selatan. Kesesuaian program pemerintah dengan kebutuhan kebutuhan masyarakat dan tata nilai lokal yang berkembang akan menjamin efektivitas dan keberlanjutan program di masa mendatang (De Freitas and Tagliani, 2009 dan Maryam et al., 2012).

Ketiga, akses ekonomi. Implementasi strategi prioritas pengembangan perikanan cumi hendaknya mampu membuka akses ekonomi yang lebih baik bagi nelayan, pengolah, dan pedagang ikan kecil di setiap wilayah basis pengembangan cumi. Oleh karena dukungan sarana dan prasarana, seperti tempat pendaratan ikan, tempat penyimpangan dingin, pabrik es, serta prasarana jalan dan pelabuhan pendaratan perlu dibenahi, sehingga memudahkan kegiatan produksi dan distribusi produk cumi ke pasar tujuan. Menurut Su et al. (2106) dan Schuhbauer and Sumaila (2016), kemudahan akses ekonomi akan mencegah terjadinya praktek pengaturan harga dan penguasaan pasar oleh kelompok masyarakat tertentu dengan memarjinalkan kelompok masyarakat lainnya. Keempat, prinsip partisipatif. Implementasi strategi pengembangan termasuk pada perikanan cumi akan dapat berjalan dengan baik jika melibatkan partisipasi semua pihak yang terkait (stakeholders) yaitu pemerintah daerah, dunia usaha, LSM, perguruan tinggi dan masyarakat. Adanya partisipasi seluruh pihak akan mewujudkan rasa memiliki dan tanggungjawab untuk bersama-sama menjaga kelestarian sumberdaya perikanan cumi.

Kelima, akuntabilitas dan transparansi. Implementasi strategi prioritas pengembangan perikanan cumi juga harus mengedepankan prinsip akuntabilitas dan transparansi dalam pelaksanaannya. Akuntabilitas artinya segala kebijakan dan peraturan yang dikeluarkan oleh Kabupaten Bangka Selatan dalam pengelolaan dan pengembangan perikanan cumi harus dapat dipertanggungjawabkan kepada publik. Di samping itu, segala kebijakan politik, publik dan peraturan daerah harus transparan dan dapat diketahui oleh seluruh lapisan masyarakat terutama yang berkaitan dengan pengembangan sarana dan prasarana yang biasanya membutuhkan anggaran besar. Hal ini penting untuk mewujudkan pemerintahan yang bersih dan bebas dari praktek KKN. Sekitar $75 \%$ kepercayaan masyarakat terhadap suatu pemerintahan dipengaruhi oleh track record yang bersih dan program yang pro-rakyat (Nurdin and Grydehoj, 2014).

\section{KESIMPULAN}

Selama periode 2009-2016, produksi perikanan cumi di Kabupaten Bangka Selatan rata-rata 4187,87 ton dengan nilai kontribusi mencapai Rp 87.736.058.000 setiap tahunnya. Dari jumlah tersebut, sebagian besar merupakan kontribusi bagan perahu $(63,50 \%)$. Wilayah basis pengembangan perikanan cumi menggunakan: (1) bagan tancap adalah Kecamatan Tukak Sadai $(L Q=7,96)$, Kecamatan Lepar Pogok (LQ = 3,55), dan Kecamatan Toboali $(\mathrm{LQ}=2,33)$, (2) bagan perahu adalah Kecamatan Kepulauan Pongok (LQ $=1,46$ ), dan (3) pancing cumi adalah Kecamatan Simpang Rimba (LQ = 1,93), Kecamatan Batu Betumpang (LQ = 1,93), Kecamatan Toboali (LQ = 1,65), dan Kecamatan Lepar Pongok $(\mathrm{LQ}=1,51)$. Sedangkan strategi prioritas pengembangan adalah pembinaan sumberdaya manusia perikanan cumi $(\mathrm{RK}=$ 0,228; IR $=0,05$ ) di setiap wilayah basis pengembangan. Perbaikan manajemen usaha perikanan cumi $(\mathrm{RK}=0,205 ; \mathrm{IR}=0,05)$ menjadi prioritas kedua dalam mendukung 
pengembangan perikanan cumi sebagai komoditas unggulan lokal.

\section{DAFTAR PUSTAKA}

Baer, C. and T. Brown. 2006. Location quotients: a tool for comparing regional industry compositions. Advanced Economic and Market Analysis Group-SRD, Department of Workforce Development. Indiana. 15 p.

Baskoro, M.S. 2016. Atraktor cumi-cumi rekayasa teknologi pengayaan sumberdaya cumi-cumi, efisiensi penangkapan dan konservasi lingkungan. Departemen PSP FPIK IPB. Bogor. 35 hlm.

Dinas Kelautan dan Perikanan Provinsi Kepulauan Bangka Belitung (DKP). 2017. Statistik perikanan tangkap tahun 2016. DKP Provinsi Kepulauan Bangka Belitung. Pangkal Pinang. $42 \mathrm{hlm}$.

De Freitas, M.D. and P.R.A. Tagliani. 2009. The use of GIS for the integration of traditional and scientific knowledge in supporting artisa-nal fisheries management in Southern Brazil. J. of Environmental Management, 90(6): 2071-208.

https://doi.org/10.1016/j.jenvman.200 7.08.026

Fauzi, A. dan S. Anna. 2002. Evaluasi status keberlanjutan pembangunan perikanan: aplikasi pendekatan rapfish (Studi kasus perairan pesisir DKI Jakarta). J. Pesisir dan Lautan Indonesia, 4(2): 36-49.

Fitriyashari A, A. Rosyid, dan D. Ayunita. 2014. Analisis kebutuhan perbekalan kapal penangkap ikan di Pelabuhan Perikanan Pantai Tasikagung, Rembang. J. of Fisheries Resources Utilization Management and Technology, 3(3): 122-130.
Schuhbauer, A. and U.R. Sumaila. 2016. Economic viability and small-scale fisheries - a review. J. of Ecological Economics, 124(1): 69-75. https://doi.org/10.1016/j.ecolecon.201 6.01.018

Maina, I., S. Katsanevakis, S. Kavadas, and S. Somarakis. $2016 . \quad$ A methodological approach to identify fishing grounds: A case study on Greek trawlers. Fisheries Research, 183(1): 326-339.

https://doi.org/10.1016/j.fishres.2016. 06.021

Maryam, S., E.M. Katiandagho, dan I.J. Paransa. 2012. Pengaruh perbedaan pancing jigs beradium dan berlampu terhadap hasil tangkapan sotong di Perairan Pantai Sario Tumpaan Kota Manado. J. Ilmu dan Teknologi Perikanan Tangkap, 1(1): 18-21.

Mustaruddin, M.S. Baskoro, dan B. Purwanto. 2015. Pengembangan investasi usaha perikanan tangkap unggulan di Bau-bau, Sulawesi Tenggara. Prosiding Seminar Nasional Perikanan Tangkap VI, 22 Oktober 2015. Hlm.: 193-207.

Mustaruddin, Nasruddin, Sadarun, F. Kurniawan, dan M.S. Baskoro. 2014. Karakteristik perairan dalam kaitannya dengan pengembangan usaha perikanan pelagis besar di Kabupaten Aceh Jaya. Buletin PSP, 20: 69-80.

Nurdin, N., and A. Grydehoj. 2014. Informal governance through patron-client relation-ships and destructive fishing in Spermonde Archipelago, Indonesia. J. of Marine and Island Cultures, 3(2): 54-59.

http://doi.org/10.1016/j.imic.2014.11. 003

Pascoe, S., A. Doshi, Q. Dell, M. Tonks, and R. Kenyon. 2014. Economic value of recreational fishing in Moreton Bay and the potential impact of the marine 
park rezoning. J. of Tourism Management, 41(1): 53-63. https://doi.org/10.1016/j.tourman.201 3.08.015

PEMDA Kabupaten Bangka Selatan. 2011 2017. Statistik perikanan tangkap Kabupaten Bangka Selatan. PEMDA Kabupaten Bangka Selatan. Toboali.

PEMDA Kabupaten Bangka Selatan. 2011. Rencana pembangunan jangka menengah di Kabupaten Bangka Selatan RPJMD 2011-2015. Toboali.

Rosalina, D., A. Wahyu, dan M. Dini. 2011. Analisis tangkapan lestari dan pola musim penangkapan cumi-cumi di Pelabuhan Nusantara SungailiatBangka. Maspari J., 2(1): 26-38. ttps://doi.org/10.36706/maspari.v2i1. 1141

Saaty, T.L. 1993. Pengambilan keputusan bagi para pemimpin. PT. Pustaka Binaman Pressindo, Jakarta. 270hlm.

Su, M.M., G. Wall, and M. Jin. 2016. Island livelihoods: fishing and tourism at
Long Islands, Shandong Province, China. J. Ocean \& Coastal Management, 122(1): 20-29. http://doi.org/10.1016/j.ocecoaman.2 015.11.014

Sumaila, U.R., C. Bellmann, and A. Tipping. 2016. Fishing for the future: An overview of challenges and opportunities. J. of Marine Policy. 69(1): 173-180.

http://doi.org/10.1016/j.marpol.2016. 01.003

Oktariza, W., B. Wiryawan, M.S. Baskoro, R. Kurnia, dan S.H. Suseno. 2016. Model bio-ekonomi perikanan cumicumi di Perairan Kabupaten Bangka, Provinsi Kepulauan Bangka Belitung. Marine Fisheries, 7(1): 97-107. http://doi.org/10.29244/jmf.7.1.97107

Received : 31 January 2019

Reviewed : 12 March 2019

Accepted : 18 June 2019 
